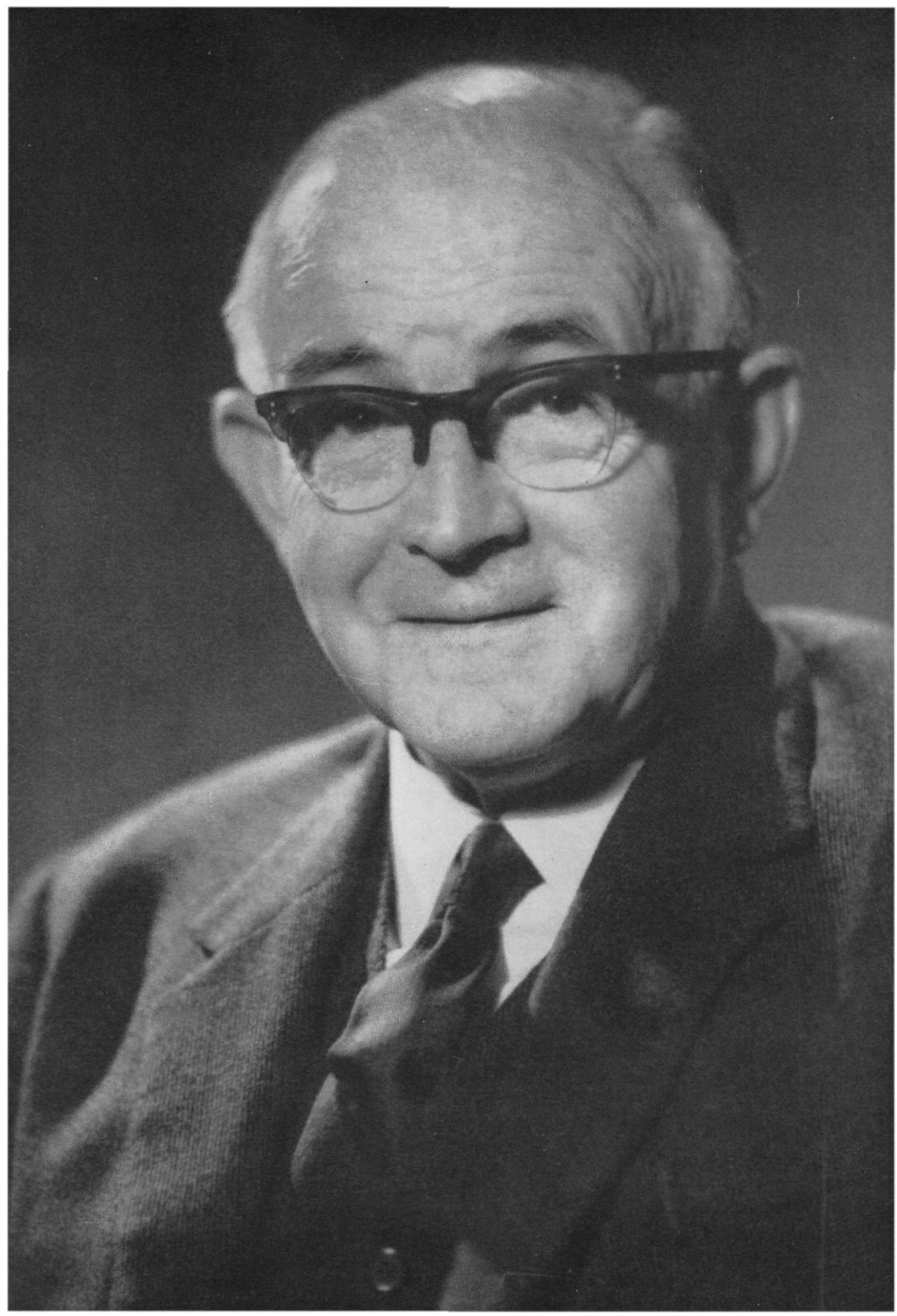




\title{
ALEXANDER HUGH MCDONALD
}

\author{
1908-1979
}

Alex McDonald joined the Roman Society in 1934, at the time when he took up his first lecturing post at University College, Nottingham. He was elected to Council in 1958. In 1966 he became a Vice-President; and he was President from 1971 to 1974.

He was one of a group of scholars from the Antipodes who over the years have made an outstanding contribution to classical studies in this country. He was born in New Zealand (where he took his first degree at Auckland in 1928 before going to read Classics at Cambridge), but his later associations in the southern hemisphere were rather with Australia, and especially with Sydney, where he taught-first as Reader and later as Professor of Ancient World History-from 1939 to 1951. The title of his chair invited him to take a broad view of his assignment and this matched his own inclination. Indeed, for many years he was widely known and highly regarded throughout Australia not only as a Roman historian, but also as an expert on Pacific problems. During the years of the Pacific war he was drawn increasingly into government work. He acted regularly as a news commentator for the Australian Broadcasting Commission; for several years he produced its Current Affairs Bulletin for the Australian Army; and from 1946 to I95I he served on the Australian Colonial Services Appointments Board. During these years he published a critique of fapanese Imperialism (1944) and edited a book of essays on Trusteeship in the Pacific (1948).

For much of this time he was also carrying a heavy teaching load in the University of Sydney. Besides running his own Department he was also for one year acting head of the Latin Department; and he regularly lectured to large classes of between 400-500 students at 3.00 p.m. in the heat of the Sydney sun, as well as duplicating his lectures in the evening for those taking an 'evening degree '. These years in Australia were noteworthy for his display of indefatigable energy, the variety of his obligations conscientiously and imaginatively fulfilled and the wide range of his teaching, which took in Egyptian art and archaeology as well as the normal range covered by a specialist in Greek and Roman history. It is indeed not surprising that when in $195 \mathrm{I}$ he was about to return to England he was heard to declare 'Well, I've done ten years hard ....'

His return to a Fellowship at Clare College and a lectureship in Ancient History in the University of Cambridge in 1952 marked the beginning of a less hectic time with fewer pressures, and gave him the opportunity to consolidate his reputation as a scholar in his own field. His main interest was in the middle Roman republic and especially in the fourth decade of Livy, along with Polybius the primary source for the period. His concern with Livy went back to 1933 , when after taking a first in Part II of the Classical Tripos at Cambridge he spent a fruitful year working under Ulrich Kahrstedt at Göttingen, and doing most of the spade-work for his Cambridge doctoral thesis on Livy's sources. This work was to culminate in his Oxford Classical Text of Livy, books xxxi-xxxv, published by the Clarendon Press in 1965, an edition described in $7 R S$ 1967, 278-80, as a work of outstanding scholarship, which displayed shrewd judgement in its treatment of conjectures. Its preface marked a break-through in the study of the manuscripts and the establishment of a stemma. About the same time he also published a book for the general reader on Republican Rome (1966), which reflected his long preoccupation with Roman imperialism in Italy and beyond and contained many wise and penetrating observations derived in part from his own practical experience in the Pacific area. Over the years he also published a series of papers, some, like those dealing with the treaty of Apamea ( $F R S, 1967$ and 1969 ), concerned with detailed points of scholarship involving Livy's text, others on more general aspects of Roman imperialism. In 1954 he held a visiting professorship at Chicago and in 1966 Membership of the Institute for Advanced Study at Princeton, N.J. His scholarship was widely acclaimed, and received recognition in honorary degrees conferred on him by the Universities of Glasgow and Auckland, in his Fellowship of the Australian Historical Association and in his election in 1968 to Fellowship of the British Academy.

Alex McDonald was an eminently likeable man with a warm and friendly disposition, invariably ready in his help to young and old alike. It made little difference whether the request came from a group of undergraduates planning to take an elephant over the Alps in Hannibal's wake and anxious to choose the right pass, or an eminent scholar seeking expert counsel on Hannibal's Legacy to Italy and the Mediterranean world. The response was always prompt and generous, the advice soundly based and well considered. As a collaborator (the present writer can testify) he was excellent to work with, knowledgeable but never dogmatic, and always prepared to weigh the pros and cons of any suggestion. To his pupils he was a good guide and stimulated them to think for themselves. Nor was his interest in them confined to the academic field, for he had a great zest for sport. With his stocky figure he had been an effective scrum half at Rugby Football and was at one time New South Wales champion at squash, a game in which he was apt to produce surprises for opponents who took him on in ignorance of his expertise. Whenever the All Blacks Rugby team from New Zealand were touring in this country he was in personal touch with them, and it is said that he could give a 
very tolerable rendering of their war-cry. He was a good college man who encouraged and thrived on community life. As Senior Tutor at Clare he was responsible for introducing an up-to-date filing system for student records; and as wine steward he laid down a cellar which still gives satisfaction to the fellows and guests of that college. Whether in England or Australia he took a pleasure in encouraging the founding of dining clubs to foster academic fellowship and discussion.

The beginning of his Presidency of the Society was overshadowed by the sudden death of Miss Joyce Southan, the librarian, and the office staff recall with gratitude his calm and effective help during the time of distress which this caused and the subsequent period of reorganization. He was a cool and experienced administrator and gave many hours to the needs of the library, to the drafting of the regulations for the Hugh Last Fund, and later to tackling the problems which sprang from the introduction of V.A.T. Despite a serious attack of hepatitis (from the effects of which he never wholly recovered) he guided the Society wisely through a series of problems and in doing so made lasting friends of all with whom he worked.

From I973 onward he and his wife Joan (née McIlrath) lived in retirement at Perth, W.A., where he held an honorary Research Fellowship in the University of Western Australia and continued to work on the Oxford Livy. His annual visits to this country were a source of satisfaction to his friends and colleagues in England. By them and by classical scholars generally his death will be greatly lamented.

F.W.W. 